\title{
Additional stimulation of sGC on top of standard treatment with ARB's may offer a new therapeutic approach for the treatment of diabetic nephropathy resistant to $A R B$ treatment alone
}

\author{
Markus Alter ${ }^{1,2,3}$, Ina Ott ${ }^{1}$, Karoline von Websky ${ }^{1,2}$, Oleg Tsuprykov ${ }^{1,2}$, Yuliya Sharkovska ${ }^{2}$, Katharina Krause-Relle ${ }^{2,3}$,
} Jens Raila ${ }^{3}$, Andrea Henze ${ }^{3}$, Axel Kretschmer ${ }^{4}$, Johannes-Peter Stasch ${ }^{4,5}$, Berthold Hocher ${ }^{2,3^{*}}$

From 5th International Conference on cGMP: Generators, Effectors and Therapeutic Implications Halle, Germany. 24-26 June 2011

\section{Background}

Riociguat is the first of a new class of drugs, the soluble guanylate cyclase (sGC) stimulators. Riociguat has a dual mode of action: it sensitizes sGC to the body's own NO and can also increase sGC activity in the absence of NO. The NO-sGC-pathway is impaired in many cardiovascular diseases such as heart failure, pulmonary hypertension and diabetic nephropathy (DN). DN leads to high cardiovascular morbidity and mortality. There is still a high unmet medical need. The urinary albumin excretion rate is a predictive biomarker for these clinical events. Therefore, we investigated the effect of riociguat, alone and in combination with the angiotensin II receptor antagonist (ARB) telmisartan on the progression of DN in diabetic eNOS knock out mice, a new model closely resembling human pathology.

\section{Methods}

Seventy-six male eNOS knockout C57BL/6J mice were divided into 4 groups after receiving intraperitoneal high-dose streptozotocin: telmisartan $(1 \mathrm{mg} / \mathrm{kg})$, riociguat $(3 \mathrm{mg} / \mathrm{kg})$, riociguat+telmisartan (3 and $1 \mathrm{mg} / \mathrm{kg}$ ), and vehicle. Fourteen mice were used as non-diabetic controls. After 12 weeks, urine and blood were obtained and blood pressure measured. Glucose concentrations were highly increased and similar in all diabetic groups.

* Correspondence: berthold.hocher@charite.de

${ }^{2}$ Center for Cardiovascular Research, Charité, Campus Mitte, Berlin, Germany Full list of author information is available at the end of the article

\section{Results}

Riociguat, alone $(105.2 \pm 2.5 \mathrm{mmHg}$; mean \pm SEM; $\mathrm{n}=14)$ and in combination with telmisartan $(105.0 \pm 3.2 \mathrm{mmHg}$; $\mathrm{n}=12$ ), significantly reduced blood pressure versus diabetic controls $(117.1 \pm 2.2 \mathrm{mmHg} ; \mathrm{n}=14 ; \mathrm{p}=0.002$ and $\mathrm{p}=0.004$, respectively), whereas telmisartan alone $(111.2 \pm 2.6 \mathrm{mmHg})$ showed a modest blood pressure lowering trend $(\mathrm{p}=0.071 ; \mathrm{n}=14)$. The effects of single treatment with either riociguat $(97.1 \pm 15.7 \mu \mathrm{g} / \mathrm{d} ; \mathrm{n}=13)$ or telmisartan $(97.8 \pm 26.4 \mu \mathrm{g} / \mathrm{d} ; \mathrm{n}=14)$ did not significantly lower albumin excretion on its own ( $\mathrm{p}=0.067$ and $\mathrm{p}=0.101$, respectively). However, the combined treatment led to significantly lower urinary albumin excretion $(47.3 \pm 9.6 \mu \mathrm{g} / \mathrm{d} ; \mathrm{n}=12)$ compared to diabetic controls $(170.8 \pm 34.2 \mu \mathrm{g} / \mathrm{d} ; \mathrm{n}=13 ; \mathrm{p}=0.004)$, and reached levels similar to non-diabetic controls $(31.4 \pm 10.1 \mu \mathrm{g} / \mathrm{d}$, $\mathrm{n}=12$ ).

\section{Conclusion}

Riociguat significantly reduced urinary albumin excretion in diabetic eNOS knock out mice that were refractory to treatment with ARB's alone. Patients with diabetic nephropathy refractory to treatment with ARB's have the worst prognosis among all patients with diabetic nephropathy. Our data indicate that additional stimulation of sGC on top of standard treatment with ARB`s may offer a new therapeutic approach for patients with diabetic nephropathy resistant to ARB treatment.

\footnotetext{
Author details

'Department of Nephrology, Charité, Campus Benjamin Franklin, Berlin, Germany. ${ }^{2}$ Center for Cardiovascular Research, Charité, Campus Mitte, Berlin,
} 
${ }^{5}$ Institute of Pharmacy, Martin-Luther-University of Halle, Germany.

Published: 1 August 2011

doi:10.1186/1471-2210-11-S1-P1

Cite this article as: Alter et al: Additional stimulation of $\mathrm{sGC}$ on top of standard treatment with ARB's may offer a new therapeutic approach for the treatment of diabetic nephropathy resistant to ARB treatment alone. BMC Pharmacology 2011 11(Suppl 1):P1.

Submit your next manuscript to BioMed Central and take full advantage of:

- Convenient online submission

- Thorough peer review

- No space constraints or color figure charges

- Immediate publication on acceptance

- Inclusion in PubMed, CAS, Scopus and Google Scholar

- Research which is freely available for redistribution

Submit your manuscript at www.biomedcentral.com/submit
Ciomed Central 